\title{
The Rapid Method of Soil Identification Based on Remote Sensing and Geographic Information Systems (Case Study of Moramo Watershed)
}

\author{
Jufri Karim ${ }^{1}$, Totok Gunawan ${ }^{2}$, Tukidal Yunianto ${ }^{2}$, Hasbullah Syaf ${ }^{3} \&$ Syamsu Alam $^{3}$ \\ ${ }^{1}$ Department of Geography, Faculty of Earth Sciences and Technology, Halu Oleo University, Kendari 93232 \\ Southeast Sulawesi, Indonesia \\ ${ }^{2}$ Department of Remote Sensing, Faculty of Geography, Gadjah Mada University, Yogyakarta, Indonesia \\ ${ }^{3}$ Department of Soil Science, Faculty of Agriculture, Halu Oleo University, Kendari 93232 Southeast Sulawesi, \\ Indonesia \\ Correspondence: Hasbullah Syaf, Department of Soil Science, Faculty of Agriculture, Halu Oleo University, \\ Kendari 93232 Southeast Sulawesi, Indonesia. Tel: 62-852-4232-5675. E-mail: hassyaf@yahoo.co.id
}

Received: August 25, 2020 Accepted: September 5, 2020 Online Published: October 27, 2020

\begin{abstract}
The field-tested samples are done by stratified random sampling. Soil classification was obtained through observation of field profile morphology and soil analysis in the laboratory followed by supporting data such as temperature and rainfall. The Moramo River Basin (DAS) was used as the location of the case study in this experiment by observing 13 soil profiles. Soil properties and characteristics were observed for soil texture, clay mineral, soil $\mathrm{pH}\left(\mathrm{H}_{2} \mathrm{O}\right.$ and $\left.\mathrm{KCl}\right)$, soil cation, saturation bases, and $\mathrm{C}$-organic. The soil naming was done to subgroup category based on Soil Taxonomy System in 2010 and paired with the land classification system of Soil Research Center in 1983, and WRB-FAO in 2006. The result showed that the accuracy of landform interpretation $89.6 \%$, rocks $92.19 \%$, accuracy of land use interpretation $90.63 \%$, and accuracy of soil mapping $90.00 \%$, so that the image ALOS AVNIR-2 can be utilized well to obtain parameter of the land unit for land mapping. The result of image data processing through RGB 341 composite image showed a high unidirectional frequency filter, histogram equalization, and analyzed with Geographic Information System, 15 units of landform, five-rock units. nine land-use units and 11 sub-soil sub-groups were obtained. The results of the soil classification in the Moramo Watershed (DAS) region in the subgroup category obtained 11 subgroups of land consisting of Lithic Udorthents, Typic Udifluvents, Aeric Endoaquents, Typic Fluvaquents, Typic Dystrudepts, Typic Eutrudepts, Ruptic-Alfic Eutrudepts, Lithic Dystrudepts, Oxyaquic Eutrudepts, Fluvaquentic Epiaquepts, Typic Endoaquepts.
\end{abstract}

Keywords: image processing, land mapping, visual interpretation

\section{Introduction}

Indonesia has a land area of about $1.900 .000 \mathrm{~km}^{2}$ consisting of 17.000 islands (Warta IDSN, 2009) with various physical conditions in the region, if it is carried out by conventional land mapping, it will spend a large amount of energy and costs in the long period (Soil Survey Staff, 2017). According to Alavipanah et al. (2010), the use of satellite data and geographic information system techniques in providing thematic maps tend to save $40-60 \%$ cost and time, improve the precision and accelerate data updates compared to other methods. One of the important information needed that is related to regional development plans is about soil information.

As one of the land's elements which are the result of five soil-forming factors (parent material, climate, biology, terrain and time (Zhang et al., 2017; Minasny \& McBratney, 2016), information of soil characteristic and its response to management in evaluating the use of land resources is urgent both in agriculture or forestry field for feasibility studies and planning in regional development and various engineering projects. In achieving the purpose, it is necessary to determine the external feature and divide it into relatively homogeneous units and map the distribution of these units so it allows to predict these areas and determine the characteristics of the map units so that the policies could be issued regarding with potential land use and its response to management changes. In fact, the availability of land information in most areas, especially in the Southeast Sulawesi region, is still on a smaller scale (1: 250000 scale).

The information obtained on this scale is only in the form of soil units in the high category (suborder), the 
definitions are less accurate, and the data on the properties of the soil given are not detailed. Thus, this information is only feasible for macro and meso level planning, while regions with rapid rates of change such as watershed areas with intensively used land require planning at the micro level due to the continued exploitation of land resources. In obtaining of detailed land information on a conventional (terrestrial) land survey and mapping, it is very inefficient in time, cost, and energy, if it is carried out on large areas and heavy terrain (Yang et al., 2020). For this reason, an effective and efficient survey method is required by remote sensing survey methods (Jensen, 2002; Stump et al., 2016; Pahlayand-Rad et al., 2016; Yang et al., 2020).

The survey methods use remote sensing is conducted to reduce field activities and costs and increasing the map detail in the presentation of land parameters with the distribution of soil types. Watershed (DAS) as a natural system, is a place where hydrology biophysical processes and socio-economic and cultural activities of complex communities take place (Dirjen RLPS, 2009). To survive, the community tends to find areas, where the availability of resources reliable like a watershed. Natural processes and human activities in areas allow the landscape changes in the watershed area. The Moramo watershed, for example, has experienced many environmental changes, such as environmental degradation, and natural resources reduction, and land-use change due to the increase of population growth, development process, and land-use patterns. It is can be seen from the transmigration settlement units (SP) in the Moramo watershed where the implementation is not to follow the rules of spatial planning in the watershed, allowing the reduction of river air quality, erosion, pollution, and critical land forming or floods.

The rapid development of remote sensing technology today produces images that have a high spatial resolution as an Aerial Photography alternative, like ALOS Image. The implementation of satellite imagery makes it possible to have a wide area of coverage and observation, so that possible to conduct the interpretation of land elements or physical feature and culture at land surfaces such as geographical form (landform), flow patterns, flow density, rock, land use, and natural vegetation (Yunianto, 1987; Bauer, 2004; Smith \& Pain, 2009). Digital interpretation process and visually make the recording of physical parameters of the land related to the location of the distribution of soil types easier. The implementation of modern spatial information technology, such as geographic information systems (GIS) (Prahasta, 2009), digital elevation modeling and remote sensing have created new feasibility for improvement research (Mann et al., 1999; Martinez-Casasnovas 2003) in economical land mapping due to low cost and acceleration (Raoofi et al., 2004). Digital maps through remote satellite sensing imagery can accelerate the improvement of data management and make it more accurate (Mau-Crimmins and Orr 2005 in Christensen, et al., 2011). The research aims to map the soil types using remote sensing methods from ALOS AVNIR-2 imagery through the identification of soil-forming factors.

\section{Method}

\section{Place and time of research}

This research was carried out in the Moramo Watershed (DAS) Moramo District, South Konawe District, covering an area of 12,627.95 Ha. Geographically located $122^{0} 31^{\prime} 25,17$ "- 122 $42^{\prime} 10,35^{\prime \prime}$ BT and 404'51,34 "to 4014'46,16" LS. Analysis of soil samples was carried out at the Bogor Soil Research Institute Laboratory. The properties and characteristics of the soil observed consist of soil texture, clay minerals, soil $\mathrm{pH}\left(\mathrm{pH} \mathrm{H}_{2} \mathrm{O}\right.$ and $\left.\mathrm{pH} \mathrm{KCl}\right)$, soil CEC, base saturation, and organic $\mathrm{C}$.

\section{Materials and tools}

The material used in this research is the ALOS AVNIR-2 Citra in Konawe Selatan District; Geological Map of Lasusua-Kendari Sheet System Sulawesi and Sulawesi Kolaka Sheet Scale 1: 250000 1993; Map of Rupa Bumi Indonesia (RBI) Sheet 2211-63 Lapuko Scale 1: 50000 the Year 1992; Rainfall data on Moramo station and climate at Wolter Monginsidi station for the past 10 years. While the tool used consists of digital image analysis equipment, including one unit of Toshiba Laptop, with specifications: Processor Intel (R) Pentium (R) Dual CPU T3400 2.16 GHz 1.87 GB RAM; ENVI 4.5 software; ArcGIS 9.3 software and tools for observation and sampling include: Garmin Quest GPS Version 4.00; Soil Drill (Auger), Abneylevel/Clinometer, Altimeter, Munsell Soil Color Chart; room knife; machete; hoes, shovels, soil test kits, meters, raffia, and cameras.

\section{Research Methods. Pre-field stage}

Consisting of preparation and data sources collection, digital image processing, database construction, interpretation of images, and determination of samples. Data analysis is conducted with various technical production through composite image technique, filtering, and brightening. Digital Elevation Model (DEM) analysis is conducted to identify clearer reliefs in the visual interpretation of landforms, drainage patterns, drainage densities, reliefs, geology, and hydrology (Astras and Soulan Killin, 1992 in Javed et al., 2011). The mapping of land units is carried out based on the results of processing images and interpreted visually with the analysis 
approach of the land unit of soil formation by using the basic elements of interpretation and elements of geological interpretation through the Geographic Information System (GIS) analysis function on-screen digitizing. On-field phase, consisting of external observation aspects in the form of field tests was carried out to obtain the correctness of information from a predetermined sample and reinterpretation as well as observation of internal aspects in the form of soil observation both by drilling or with a soil profile (Han and Li, 2018 in Yang et al., 2019). The determination of the field test sample (field check) is conducted through stratified random sampling. The postfield phase was conducted to reinterpret toward the remote sensing images applied, soil samples analyze, soil classification, data procession, accuracy test, and analyze ALOS AVNIR-2 images ability in interpreting of land elements for soil mapping. The naming process of soil was conducted through the subgroup category based on the soil taxonomy system in 2010 and matched to The Soil Research Center Classification System in 1983, and 2006 FAO WRB-2006.

\section{Results}

\section{Geometric Correction}

The results of calculations using ENVI 4.5 software the RMS error value of the ALOS AVNIR-2 image in the study area is 0.306932 . Geometric correction results are shown in Figure 1.

\begin{tabular}{|c|c|c|c|c|c|c|c|}
\hline \multicolumn{6}{|c|}{$\theta$ Image to Map GCP List } & \multicolumn{2}{|c|}{$-0 x$} \\
\hline \multicolumn{8}{|c|}{ File Options } \\
\hline & MapX & Image $\rangle$ & $X$ Image $Y$ & \begin{tabular}{|l|l|l} 
PredictX & PredictY & Error $X$ \\
\end{tabular} & EmrorY & RMS & \\
\hline$\# 1+$ & 455918.00 & $\begin{array}{ll}0 & 9546688.004724 .41\end{array}$ & \begin{tabular}{l|l|}
1 & 5549.51 \\
\end{tabular} & $4724.10675549 .5177 \cdot 0.3033$ & 0.0077 & 0.3033 & $\hat{=}$ \\
\hline$\# 2+$ & 455940.00 & 09569906.004732 .47 & 3248.54 & $4732.46993248 .5399 \cdot 0.0001$ & -0.0001 & 0.0001 & 且 \\
\hline$\# 3+$ & 425069.00 & 09581072.001624 .52 & 2075.50 & $1624.21932075 .1836-0.3007$ & .0.3164 & 0.4365 & \\
\hline$\# 4+$ & 424159.00 & 09533088.001506 .60 & 7037.48 & 1506.60007037 .48000 .0000 & -0.0000 & 0.0000 & \\
\hline$\# 5+$ & 455924.00 & 09546688.004724 .41 & 5549.51 & 4724.71325549 .50240 .3032 & -0.0076 & 0.3033 & \\
\hline$\# 6+$ & $\begin{array}{l}425075.00 \\
<-10]\end{array}$ & 09581066.001624 .52 & $2 \quad 2075.50$ & 1624.82082075 .81650 .3008 & 0.3165 & $0.4367>$ & $\underline{v}$ \\
\hline Goto & On/Off & Update & Hide List & & & & \\
\hline
\end{tabular}

A

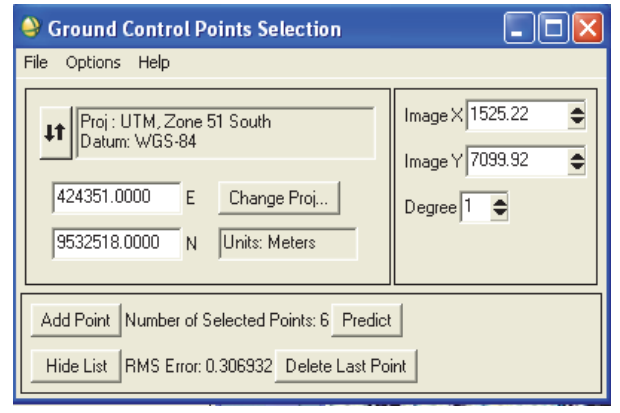

B

Figure 1. Geometric correction, where A: The value of the GCP tie point ALOS AVNIR-2 image and B: Value of $\mathrm{RMS}_{\mathrm{error}}$ geometric correction

\section{Composite Image Creation and Spatial Filtering}

The result of sharpening the composite image of RGB 341 with sharpening histogram equalization facilitates the visual interpretation of images, especially in distinguishing lithology and geological structures. Image processing results are shown in Figure 2.
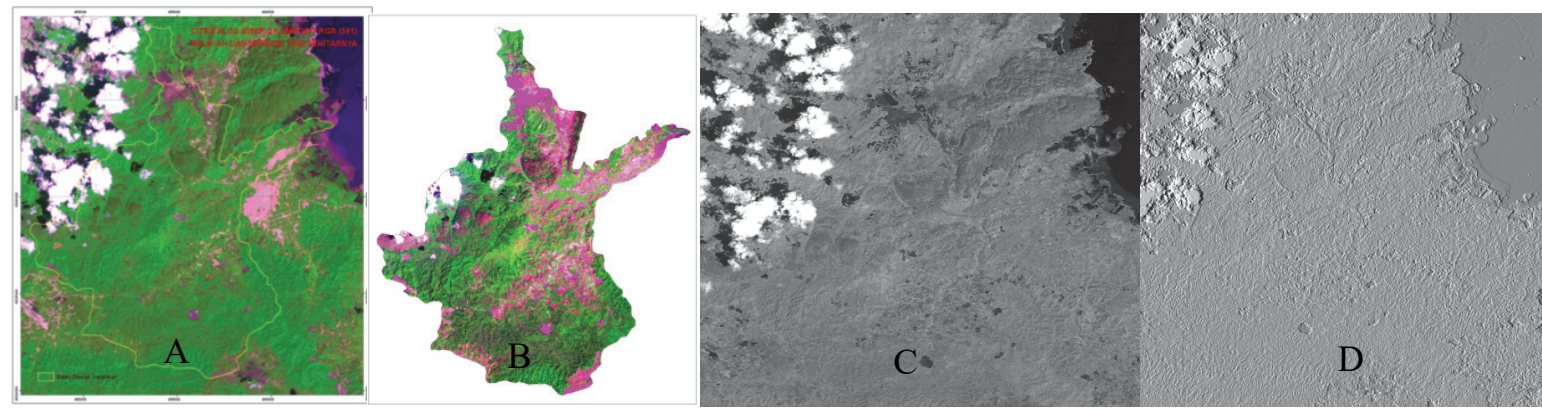

Figure 2. Sharpening the composite image of RGB 341, where A: Composite band 341 image, B: Sharpening histogram RGB 341. C: Unidirectional filtering (Laplacian), and D: Directional filtering

\section{Accuracy of landscape interpretation}

The accuracy of landforms was conducted by comparing the results of interpretation with conditions in the field. Of the 64 sample points specified, 57 were correct, so that the accuracy of landforms is obtained at $89.06 \%$. The accuracy of landscape classification is shown in Table 1. 
Table 1. Matrix of Landform Classification Accuracy in Research Sites

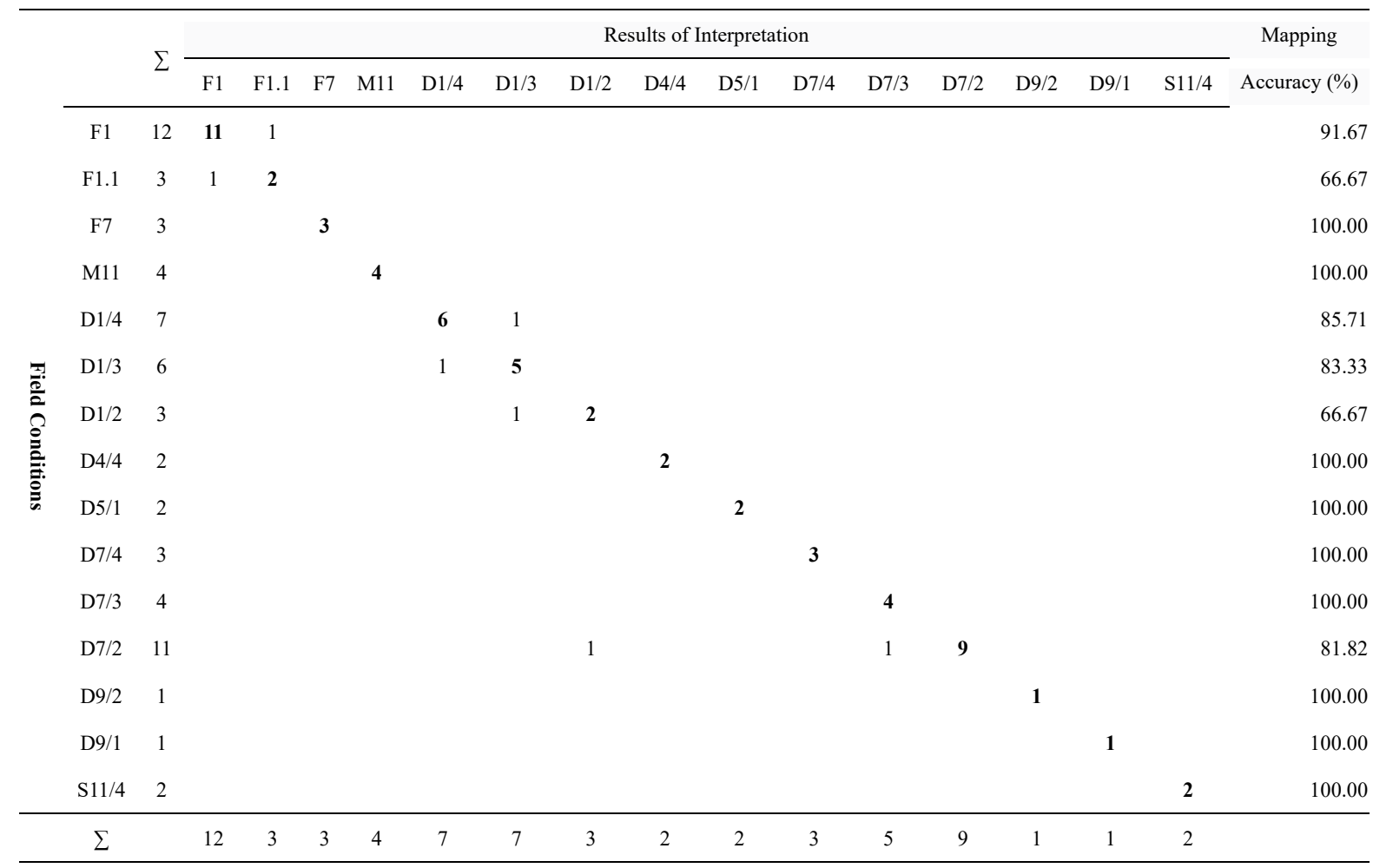

Interpretation Accuracy $=((11+2+3+4+6+5+2+2+2+3+4+9+1+1+2) / 64) \times 100 \%=89.06 \%$

Notes:

F1 : Alluvial Plains

F1.1 : Alluvial-Coluvial Plains

F7 : Flood Plains

M11 : Brackish coast alluvial plain

D1/4 : Strong eroded structural hills

D1/3 : Moderatel eroded structural hills

D1/2 : Lightly eroded structural hills
D4/4 : Isolated hills strongs erod

D5/1 : Peneplain eroded very lighty

D7/4 : Slopes of the feet slopes of structural denuded strong eroded

D7/3 : Moderately eroded structural hill feet slopes

D7/2 : Slopes of low eroded structural hills feet lightly eroded

D9/2 : Piedmont erod lightly

D9/1 : Piedmont erod very lightly

S11/4 : Dome hills strong erod

\section{Accuracy of rock interpretation}

The rock classification accuracy test is shown in Table 2.

Table 2. Matrix of rock classification accuracy at the study site

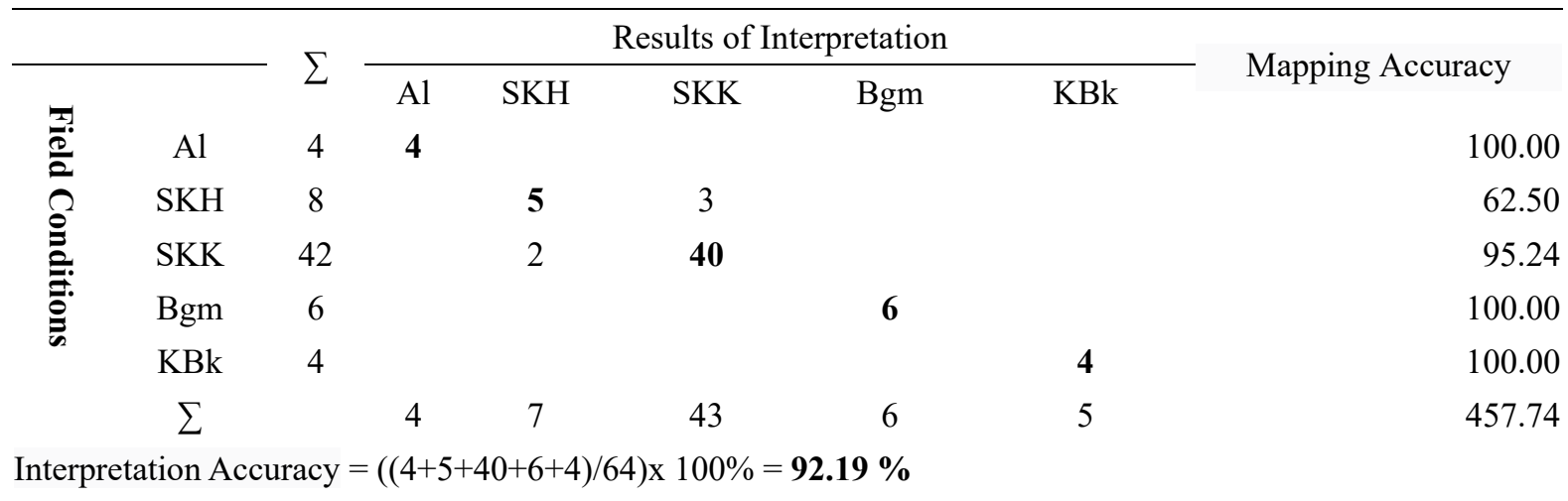

Notes: $\mathrm{Al}=$ Alluvium $\quad \mathrm{Bgm}=$ Malih limestone 
$\mathrm{SKH}=$ Fine-Grained Clastic Sedimentary

Rocks

$\mathrm{KBk}=$ Calcarenite and Coral Limestone

Test the accuracy of the interpretation of land use

From the results of the interpretation of ALOS AVNIR-2 images obtained 9 forms of land use, namely forests, bushes, grasslands, mixed gardens, moor, rice fields, ponds, mangroves, and settlements. the accuracy test of land use classification is shown in Table 3.

Table 3. Test the accuracy of the interpretation of land use in the Moramo watershed

\begin{tabular}{|c|c|c|c|c|c|c|c|c|c|c|c|c|}
\hline & & \multicolumn{9}{|c|}{ Results of Interpretation } & \multirow{2}{*}{$\sum$} & \multirow{2}{*}{ Mapping Accuracy } \\
\hline \multirow{11}{*}{ 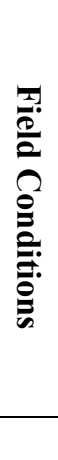 } & & $\mathrm{h}$ & $\mathrm{s}$ & pr & $\mathrm{k}$ & $\operatorname{tg}$ & SW & tk & $\mathrm{m}$ & $\mathrm{p}$ & & \\
\hline & Forest (h) & 21 & & & 1 & & & & & & 22 & 83.33 \\
\hline & Scrub Bush (s) & 1 & 5 & & 1 & & & & & & 7 & 71.43 \\
\hline & Meadow (pr) & & & 2 & & & & & & & 2 & 100.00 \\
\hline & Mixed Garden (k) & 1 & 1 & & 15 & & & & & & 17 & 81.82 \\
\hline & Tegalan $(\operatorname{tg})$ & & 1 & & & 5 & & & & & 6 & 75.00 \\
\hline & Rice Field (sw) & & & & & & 3 & & & & 3 & 100.00 \\
\hline & Pond (tk) & & & & & & & 3 & & & 3 & 100.00 \\
\hline & Mangrove (m) & & & & & & & & 1 & & 1 & 100.00 \\
\hline & Settlement $(p)$ & & & & & & & & & 3 & 3 & 100.00 \\
\hline & $\sum$ & 23 & 7 & 2 & 17 & 5 & 3 & 3 & 1 & 3 & 64 & \\
\hline
\end{tabular}

Interpretation Accuracy $=((21+5+2+15+5+3+3+1+3) / 64) \times 100 \%=\mathbf{9 0 . 6 3} \%$

\section{Accuracy of land mapping}

The Land Mapping Accuracy Test between the results of the research and the Land Map Scale of 1: 250000 is shown in Table 4.

Table 4. Accuracy of the land mapping between the results of the study and a map of land on a 1:250000 scale

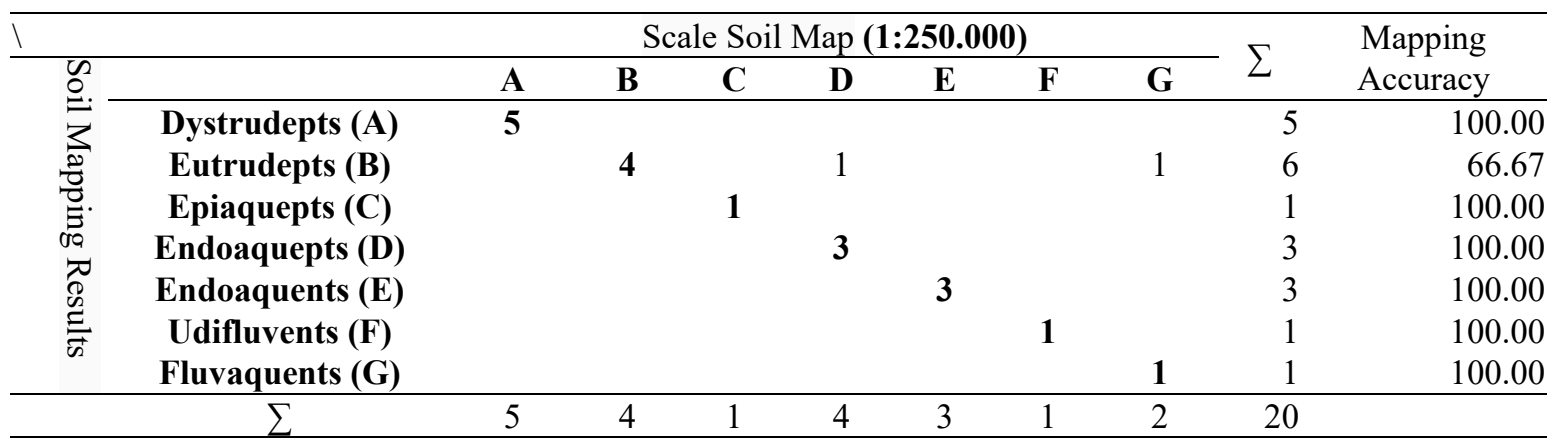

Mapping Soil Accuracy $=((5+4+1+3+3+1+1) / 20) \times 100 \%=\mathbf{9 0 . 0 0} \%$

Table 5. Classification of subgroups and their fields

\begin{tabular}{llllll}
\hline \multirow{2}{*}{ SPT } & \multicolumn{3}{c}{ Classification of Subgroups and Their Matches } & \multicolumn{2}{l}{ Large } \\
\cline { 2 - 6 } & USDA, 2010 & PPT, 1983 & WRB-FAO, 2006 & Ha & $\%$ \\
1 & Lithic Udorthents & Litosol & Lithic Leptosols Eutric & 1348.93 & 10.68 \\
2 & Typic Udifluvents & Aluvial Distrik & Haplic Fluvisols Epidystrik & 253.63 & 2.01 \\
3 & Aeric Endoaquents & Aluvial Gleiik & Gleyic Fluvisols Eutric & 60.68 & 0.48 \\
4 & Typic Fluvaquents & Kambisol Eutrik & Cambisols Eutrik & 70.26 & 0.56 \\
5 & Typic Dystrudepts & Kambisol Distrik & Haplic Cambisols Dystric & 4855.53 & 38.45 \\
\hline
\end{tabular}




\begin{tabular}{llllll}
\hline 6 & Typic Eutrudepts & Kambisol Eutrik & Haplic Cambisols Eutric & 2150.31 & 17.03 \\
7 & Fluvaquentic Epiaquepts & Aluvial Gleiik & Gleyic Fluvisols & 430.77 & 3.41 \\
8 & Lithic Dystrudepts & Kambisol Litik & Epileptic Cambisols Dystric & 2039.48 & 16.15 \\
9 & Ruptic-Alfic Eutrudepts & Kambisol Gleiik & Endogleyic Cambisols Eutric & 609.14 & 4.82 \\
10 & \multirow{2}{*}{ Oxyaquic Eutrudepts } & Kambisol Gleiik & $\begin{array}{l}\text { Endogleyic Cambisols Eutric } \\
\text { Oxyaquic }\end{array}$ & 380.39 & 3.01 \\
11 & Typic Endoaquepts & Gleisol Eutrik & Haplic Gleysols Eutric & 428.83 & 3.40 \\
& & Total & & $\mathbf{1 2 6 2 7 . 9 5}$ & $\mathbf{1 0 0 . 0 0}$ \\
\hline
\end{tabular}

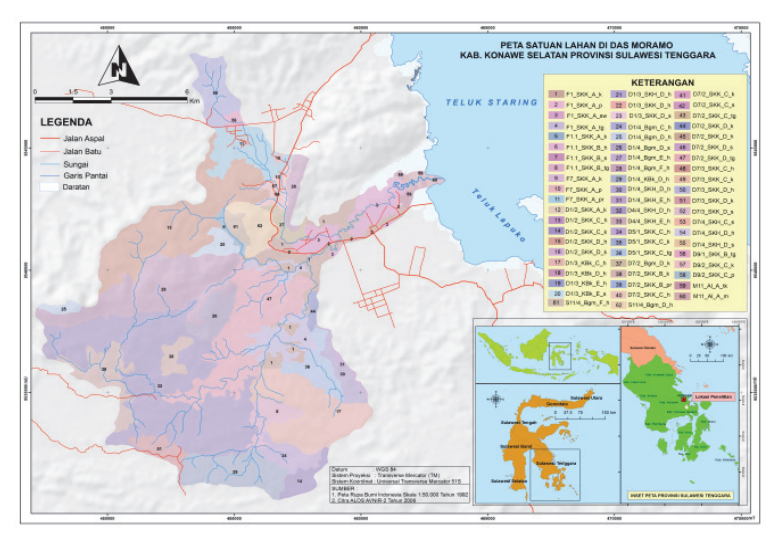

Land Unit Map

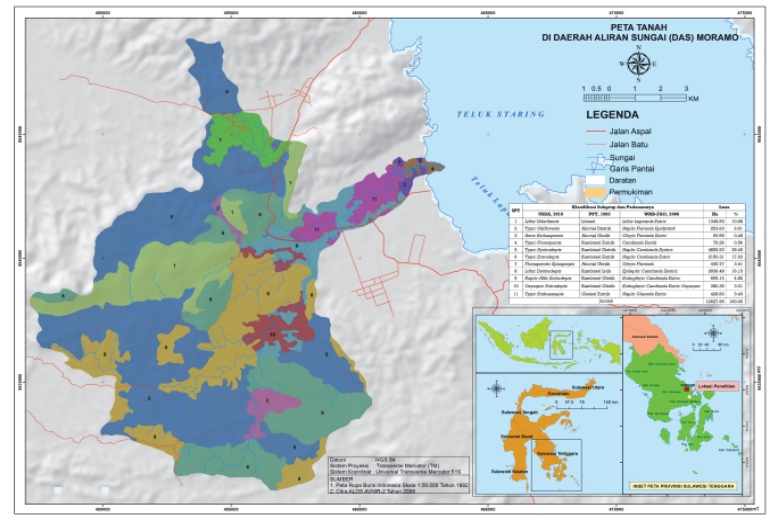

Moramo Watershed Soil Map

Figure 3. Map of the Land Unit and Land Map of the Subgroup Category in the Moramo Watershed

\section{Discussion}

A geometric correction was carried out to return the position of the pixel to the actual position both the shape or position on the earth's surface on a map with certain projections (Danoedoro, 1996; Danoedoro, 1992). A correction was carried out by the image to map method, with 6 points of GCP (Ground Control Point) consider the various topography from flat to hilly area. The process of resampling spectral values using the nearest neighbor (closest neighbor) algorithm (Lillesand and Keifer 2006 in Avtar et al, 2011). According to Jensen (1986), the maximum limit value of the quality of geometric correction is 0.5 for the total RMS.

RGB composite image (341), caused by this channel can highlight vegetation in green, open land (dry conditions) from sand deposits in pink, moist purple soil, and bluish-purple water and pink-colored settlement, purplish moist soil, bluish-purple water, and the settlement with a bright pink color. Besides that, the feature of landform, topography, and lithology in the study area could be seen making it easier to interpret the land elements for soil mapping.

Based on the results of sharpening with directional and unidirectional filters, the obtained high pass undirectional filter (Laplacian) type which has the ability to identify and analyze geological structures, geological boundaries, and landform units. This filter is accentuated by the appearance of the image in all directions and is able to accentuate the curved edges which are not ideal lines Sharpening Contrast (Figure 2).

The results of the interpretation of elements of land units were obtained from the pre-processing process until image processing. The soil mapping unit is a united of three-unit elements, namely the land unit, the parent material unit (lithology), and the area unit (landscape phenomenon). The difference in unit maps in various categories of soil maps is in the accuracy of each element of the map unit. The application of these three elements can provide a clear picture of an area about the state of the land and its landscape (SSSA, 1994; Darmawijaya, 1997).

The accuracy of the data from the interpretation of ALOS AVNIR-2 imagery was conducted by comparing the results of the interpretation of the land unit with the actual conditions in the field through field checks (Wahyunto, et al., 2004). An interpretation result data has a high level of validity and accuracy if there is a match between the 
results of the interpretation and the results of the field test (Short, 1982). Interpretation results tested for accuracy in this study are the results of the interpretation of land unit parameters in soil mapping in the form of land, rocks, and land use as well as land mapping tests in the type of category (great group). The method of testing the accuracy of the results of the interpretation in this study is to use the Confusion Matrix Calculation Method (Short, 1982 in Ashar (2010); Wahyunto et al., 2004)

Landscape analysis can be used as one of the analysis methods in studying land and its characteristics in an area for soil mapping activities (Sartohasi, 2010). Based on the interpretation of ALOS AVNIR-2 images and supported by secondary data and field testing, through the uniformity of rock properties, and topography, 4 (four) types of origin was obtained in the study area and can be broken down into 15 landform units namely Alluvial Plain, Alluvial-Coluvial Plains, Floodplains, Brackish Alluvial Plains, Strongly eroded Structured Hills, Medium Abrasive Structured Structural Hills, Structural Hills Terududasi lightly eroded, Isolated Hills Strongly eroded, Plains Nearly Lightened, Very Slightly Structural Hills Slope Strong erosion, foot slope of the structural slope with moderate erosion, the slope of structural leg slab, lightly eroded, Piedmont eroded lightly, Piedmont eroded very lightly, and strong eroded dome. The accuracy of landforms was conducted by comparing the results of interpretation with conditions in the field. Of the 64 sample points specified, 57 was correct. So that the accuracy of landforms is obtained at $89.06 \%$ (Table 1). When linked to the accuracy limit that must be met by Short (1982) which is $85 \%$, the accuracy of the landform interpretation in this study is good.

The results of interpretation of ALOS AVNIR-2 imagery and rock analysis such as relief, flow patterns, vegetation, flow density, and cultural objects (Soetoto, 1995) was carried out with some image processing in the form of sharpening and filtering and assisted geographic information system programs and supported data Secondary existing and field checking, there were five-rock units namely alluvium, fine-grained clastic sediments, coarsegrained clastic sediments, poor limestones, calcarine and coral limestones. There were correct 59 points Of the 64 sample points specified. So the rock accuracy is at $92.19 \%$ (Table 2), while Table 3. shows that there were 58 correct points of 64 specified sample points. The accuracy of the interpretation of land use was at $90.63 \%$.

The slope is not obtained through the interpretation of ALOS AVNIR-2 imagery but through DEM derivatives from the RBI map which has become the standard of slope mapping accuracy. Based on the classification of slopes, obtained six classifications of slopes namely flat, sloping or wavy, wavy or slightly tilted, tilted or hilly, rather steep and steep. The accuracy of the land mapping was carried out by overlaying between the results of the mapping carried out with the Land Map of the Southeast Sulawesi Province on a 1: 250000 scale by Bakosurtanal (Bakosurtanal, 1988). Soil map on this scale is in the great group (type) category so that the test of accuracy was carried out in that category with the accuracy of the mapping is at $90.00 \%$ (Table 4 ).

Errors in soil mapping occur when overlaying process between the soil map of 1:250000 scale and the results of mapping in the type of group (great group), especially at the period of overlaying, where the land map is 1:250000, there are 4 types of Endoaquepts, three was the same land and one is the type of soil Eutrudepts. This error is found in the form of alluvial plains that are not flooded by using mixed garden land. Errors also occur in the type of soil Fluvaquents wherefrom the soil map scale of 1: 250000 there are two types of soil, but one is the type of soil Eutrudepts. This error is found in the form of the brackish alluvial coastal land with the use of mangrove land. This error is due to the generalization of large physiographic units, especially in slope classification on the Map of Soil Type of Southeast Sulawesi on a scale of 1:250000. However, from this study, it was obtained the addition of soil types from the results of this study, namely the type of soil of Udorthents. Based on the results of the USDA classification, (2010), there are as many suborder categories as there are 5 sub-categories, namely: Orthents, Fluvents, Aquents, Udepts, and Aquepts; eight Great Groups namely Udorthents, Udifluvents, Endoaquents, Fluvaquents, Dystrudepts, Eutrudepts, Endoaquepts, and Epiaquepts; 11 soil sub-groups consisting of Lithic Udorthents, Typic Udifluvents, Aeric Endoaquents, Typic Fluvaquents, Typic Dystrudepts, Typic Eutrudepts, Ruptic-Alfic Eutrudepts, Lithic Dystrudepts, Oxyaquic Eutrudepts, Fluvaquentic Epiaquepts, Typic Endoaquepts (Table 5). Table 5 showed the Typic Dystrudepts subgroup is the widest subgroup of 4855.53 ha or $38.45 \%$ of the total area of the Moramo watershed. While the narrowest subgroup is the Aeric Endoaquents subgroup which is 60.68 or $0.48 \%$ of the total area of the Moramo watershed.

In conclusion, to facilitate and accelerate the identification and analysis of land elements in soil mapping can be done by composite 341 imagery, spatial filtering, and imagery contrast enhancement. Based on the accuracy of the interpretation of land units obtained the values of the landscape of $89.06 \%$; rocks $(92.19 \%)$; and land use (90.63\%). The soil type mapping by remote sensing method of ALOS AVNIR-2 image through the identification of soilforming factors obtained the accuracy of the land mapping of $90.00 \%$. Besides, identification of soil inland mapping with the remote sensing integration method (ALOS AVNIR-2 imagery) and geographic information system can be carried out in the great group category. 


\section{Acknowledgments}

The authors gratefully thank you to Suhardin Karim, Darsan and Jufri Hamdan who have helped a lot in collecting the research data, so that this research could run smoothly.

\section{References}

(SSSA) Soil Science Society of America. (1994). Factors of Soil Formation: A Fiftieth Anniversary Retrospective. SSSA Special Publication nr 33. Madison, WI: SSSA

Alavipanaha, S. K., Matinfarb H. R., Rafiei Emamc, A., Khodaeid, K., Hasji Bagherie, R., \& Yazdan Panahf, A. (2010). Criteria for selecting satellite data for studying land resources. DESERT, 15, 83-102.

Ashar, K., \& La Ode. (2010). Landsat-7 ETM + Image Application and Geographic Information System in Solid Bitumen Surveys and Mapping (Cases in North Buton and Surrounding Districts of Southeast Sulawesi Province). Thesis. Remote Sensing Study Program, Faculty of Geography, Gadjah Mada University. Yogyakarta.

Bakosurtanal. (1988). Land System and Land Suitability Map Scale 1: 250,000, Sulawesi Sheet 2212, RePProT Series. National Survey and Mapping Coordinating Board.

Bauer, B. O. (2004). Encyclopedia of Geomorphology. Geomorphology, 1, 428-35. London: Routledge.

Christensen, S. D., Ransom, C. V., Edvarchuk, K. A., \& Rasmussen, V. P. (2011). Efficiency and accuracy of wildland weed mapping methods. Invasive Plant Science and Management, 4(4), 458-465. https://doi.org/10.1614/IPSM-D-11-00015.1

Danoedoro, P. (1996). Digital Image Processing. Theory and Application in the Field of Remote Sensing. Faculty of Geography, Gadjah Mada University. Yogyakarta.

Danoedoro, P. (2012). Introduction to Digital Remote Sensing. ANDI Yogyakarta publisher. Yogyakarta.

Darmawijaya, M. I. (1997). Land Classification; Theory Basis for Land Researchers and Agricultural Executors in Indonesia. Third print. Gadjah Mada University Press. Yogyakarta.

Director General of Land Rehabilitation and Social Forestry (RLPS). (2009). Guidelines for Monitoring and Evaluation of Watersheds (DAS).

FAO. (2006). World Reference Base for Soil Resources, by IUSS-ISRIC-FAO. World Soil Resources Reports No. 103. Rome

Javed, A., Khanday, M. Y., \& Rais, S. (2011). Watershed Prioritization Using Land Use / Land Cover Parameters: A Remote Sensing and GIS Based Approach. Journal of the Geological Society of India, 78, 63-75. https://doi.org/10.1007/s12594-011-0068-6

Jensen, \& John, R. (1986). Digital Image Processing Introductory: a Remote Sensing Perspective. Englewood Cliffs, NJ: Prentice Hall.

Jensen, L. L. F., \& Gorte, B. G. H. (2002). Principle of remote sensing, Chapter 12 Digital image classification, ITC, Enchede, The Netherlands (2nd ed).

Mann, L. K., Anthony, W. K., Virginia, H. D., William, W. H., Robert, W., Larry, R. P., \& Tom, L. A. (1999). The Role of Soil Classification in Geographic Information System Modeling of Habitat Pattern: Threatened Calcareous Ecosystems. Ecosystems, 2, 524-55. https://doi.org/10.1007/s100219900100

Martinez-Casasnovas, J. A. (2003). A spatial information technology approach for the mapping and quantification of gully erosion. Catena, 50(2-4), 293-308. https://doi.org/10.1016/S0341-8162(02)00134-0

Minasny, B., \& McBratney, A.B. (2016). Digital Soil Mapping: a Brief history and some lessons. Geoderma, 264, 301-311. https://doi.org/10.1016/j.geoderma.2015.07.017

News IDSN. (2009). Draft National Geospatial Information Law (TIGnas Bill) in Indonesian Development. Quarterly Bulletin No.10. Bakosurtanal. Bogor.

Pahlavan-Rad, M. R., Khormali, F., Toomanian, N., Brungard, C. W., Kiani, F., Komaki, C. B., \& Bogaert, P. (2016). Legacy soil maps as a covariate in digital soil mapping: a case study from Northern Iran. Geoderma, 279, 141-148. https://doi.org/10.1016/j.geoderma.2016.05.014

Prahasta, E. (2009). Geographic Information System: Basic Concepts (Geodetic and Geomatic Perspectives. First Printing Information Bandung. Bandung.

Raoofi, M., Refahi, H., Jalali, N., \& Sarmadian, F. (2004). Find out more about satellite images to map and locate 
soil erosion. Iranian J. Agric. Sci., 35(4), 797-807 (In Persian).

Sartohasi, J. (2010). Soil Geomorphology and Its Application for Disaster Risk Reduction. Speech inauguration of Professor in the Faculty of Geography on November 24th. Yogyakarta.

Short, N. M. (1982). Landsat Tutorial Workbook - Basics of Satellite Remote Sensing. Washington DC: NASA.

Smith, M. J., \& Pain, C. F. (2009). Applications of remote sensing in geomorphology. Progress in Physical Geography, 33(4), 568-582. https://doi.org/10.1177/0309133309346648

Soetoto. (1995). Image Interpretation for Geological Survey. Faculty of Geography UGM-Bakosurtanal. Yogyakarta.

Soil Survey Staff. (2010). Keys to Soil Taxonomy, USDA 11th ed. Natural Resources Conservation Service, Washington, DC.

Soil Survey Staff. (2017). Digital Soil Mapping. In Ditzler, C., Scheffe, K., \& Monger, H. C. (Eds.), Soil Survey Manual (pp.295-354). Government Printing Office, Washington, DC.

Stumpf, F., Karsten S., Thorsten B., Schönbrodt-Stitt, Buzzo S., Dumperth G., Wadoux C., Alexandre, \& Wei X. (2016). Incorporating limited field operability and legacy soil samples in a hypercube sampling design for digital soil mapping. Thomas \%J Journal of Plant Nutrition Scholten, and Soil Science. Zeitschrift fuer Pflanzenernaehrung und Bodenkunde, 179, 499-509. https://doi.org/10.1002/jpln.201500313

Wahyunto, Murdiyati, S. R., \& Ritung, S. (2004). Application of Remote Sensing Technology and Validation Tests for Detection of Spreading of Rice Fields and Land Use/Closure. Agricultural Informatics, 13, 746-769.

Yang, H., Zhang, X., Xu, M., Shao, S., Wang, X., Liu, W., Wu, D., Ma, Y., Bao, Y., Zhang, X., \& Liu, H. (2020). Hyper-temporal remote sensing data in bare soil period and terrain attributes for digital soil mapping in the Black soil regions of China. Catena, 184, 104-259. https://doi.org/10.1016/j.catena.2019.104259

Yunianto, T. (1987). Remote Sensing Image Interpretation for Land Surveys. PUSPIC UGM-Bakosurtanal. Yogyakarta.

Zhang, G., Liu, F., \& Song, X. (2017). Recent progressand future prospect of digital soil mapping: A review. $J$. Integr. Agric., 16, 2871-2885. https://doi.org/10.1016/S2095-3119(17)61762-3

\section{Copyrights}

Copyright for this article is retained by the author(s), with first publication rights granted to the journal.

This is an open-access article distributed under the terms and conditions of the Creative Commons Attribution license (http://creativecommons.org/licenses/by/4.0/). 